\title{
Propagation Method Impacts Survival and Growth of Below Grade Planted Trees
}

\author{
Michael A. Arnold ${ }^{1 *}$, Andrew R. King ${ }^{1}$, Sean T. Carver ${ }^{1}$, Donita L. Cartmill ${ }^{2}$ \\ ${ }^{1}$ Professor of Landscape Horticulture and Director of The Gardens at Texas A\&M University, former \\ Lecturer, and former Graduate Teaching/Research Assistant, respectively, Texas A\&M University, \\ Department of Horticultural Sciences, 2133 TAMU, College Station, TX 77843-2133, 979-845-1499 \\ ${ }^{2}$ Invironmental Horticulture Program Coordinator and Professor, University of Wisconsin - Platteville, \\ School of Agriculture, 312 Pioneer Tower, Platteville, WI 53518
}

Received Date: April 01, 2021; Accepted Date: April 06, 2021; Published Date: April 16, 2021;

"Corresponding author: Michael A Arnold, Professor of Landscape Horticulture and Director of The Gardens at Texas A\&M University, former Lecturer, and former Graduate Teaching/Research Assistant, respectively, Texas A\&M University, Department of Horticultural Sciences, 2133 TAMU, College Station, TX 77843-2133, 979-845-1499. Email: ma-arnold@tamu.edu

\section{Abstract}

Rooted cuttings from four clonal taxa ranging from those that grow in dry well drained soils, Chilopsis linearis (Cav.) R. Sweet 'White Storm', to those that tolerate wet soils, Vitex agnus-castus L. 'LeCompte', and with intermediate soil requirements, Nerium oleander L. (unnamed large white flowered clone) and Lagerstroemia indica L. x Lagerstroemia fauriei B. Kohne 'Basham's Party Pink', and seedlings from each of these same clones were propagated and growth concurrently in a container nursery under the same production conditions. Factorial combinations of each taxa propagated as rooted cuttings and as seedlings were transplanted to a landscape site at four planting depths $[7.6 \mathrm{~cm}$ (3 in) above grade, at grade, $7.6 \mathrm{~cm}$ ( 3 in) below grade, and $15.2 \mathrm{~cm}$ (6 in) below grade] resulting in a 4 planting depth $\mathrm{x} 2$ propagation methods $\mathrm{x} 4$ species factorial in a randomized complete block design with four blocks containing two plants of each treatment combination per block. An unexpected rapid drop from growing temperatures to $18^{\circ} \mathrm{F}\left(-8.8^{\circ} \mathrm{C}\right)$ in the $2010-2011$ winter permitted assessment of cold injury in response to the planting depth treatments. Propagation method interacted with planting depth and taxa where Lagerstroemia responses to cold damage were different among propagation method and planting depth, while Vitex and Chilopsis were not. Exposure to low temperature had only minimal effects on the canopy survival of Lagerstroemia, Chilopsis, and Vitex, whereas Nerium canopy tissue survival was substantially reduced for plants planted above grade. Planting at grade was the best treatment for most characteristics across species and propagation methods, but there were significant interactions involving both planting depth and propagation methods for some taxa. For instance, the arid climate $C$. linearis improved survival with planting above grade, but planting below grade reduced the cross-sectional trunk area of $C$. linearis regardless of propagation method. Growth indices of seedling propagated plants tended to be larger across species when planted at or above grade, but cutting propagated plants exhibited reduced reduction in growth relative to seedling trees compared to those planted at grade. When evaluating the impacts of suboptimal planting techniques, data from this study supports the importance of knowing if the plants are cutting or seedling produced if it is a species that is sensitive to this effect.

\section{Introduction}

Reports from several research programs across the United States have begun to document the adverse effects on tree establishment and survival associated with below grade planting. However, on a given site responses with different taxa of trees 
have varied. Various environmental parameters and techniques associated with transplant practices are being investigated to determine the source of these varied responses, but one aspect that has not been investigated is the impact of propagation method on tree establishment responses associated with below grade planting. One of the factors that appears to have a role in adverse responses to below grade planting is the tree's ability to tolerate low oxygen levels (hypoxia) in the root zone, a condition sometimes exacerbated by deep planting, particularly in heavy soils. Since stem tissues may be even more susceptible to hypoxia induced damage than root tissues, vegetative propagation methods which place even more stem tissue (the base and shank of rooted shoot cuttings) below grade than with seed propagated trees might be expected to result in additional damage. No currently published studies have addressed direct comparisons between cutting propagated versus seedling derived trees in relation to above or below grade planting. Responses from the few taxa tested that were cutting propagated, rather than seed derived trees, have been mixed and may be more closely associated with species responses to site conditions (Arnold et al., 2007).

Our objectives were to directly compare seedling versus cutting propagated trees from several families with different natural ecological niches relative to exposure to hypoxic conditions in conjunction with planting at various planting depths ranging from approximately $15 \mathrm{~cm}$ below grade to 7.6 $\mathrm{cm}$ above grade.

\section{Materials And Methods}

Species from families that are naturally found in a range of environments from arid to mesic and upland to bottomland sites were selected (Arnold, 2008). Each species was propagated from both seeds and softwood cuttings and grown using the same size containers and substrates in the same nursery to minimize variation associated with production conditions. All seedlings of a given species were obtained from the same plant that was propagated clonally to minimize genetic variation as a cause of differences observed between the propagation methods within a species. Clonal selections included Chilopsis linearis 'White Storm', Vitex agnus-castus 'LeCompte', Nerium oleander (unnamed large white flowered clone), Lagerstroemia indica x Lagerstroemia fauriei 'Basham's Party Pink'.

In the spring of 2009, plants were propagated from cuttings and by seed in the greenhouse and produced for transplant to the field in containers at the outdoor nursery at the Texas A\&M University Horticultural Gardens. Production conditions were typical of that used at our regional commercial nurseries. Seedlings were germinated in common propagation flats and then transplanted to \#1 nursery containers $(2.3 \mathrm{~L})$ as the first true leaves appear. Softwood cuttings were rooted in the same type of propagation flats under intermittent mist. Once rooted, they were acclimated and then transplanted to \#1 nursery containers retaining the same planting depth as the cuttings were stuck in the propagation flats. During summer, the young trees of both seed and cutting derivation were transplanted to \#3 nursery containers and moved to full sun conditions for the remainder of the growing season. Special care was taken to maintain the original substrate surface to root collar (seedlings) or original cutting sticking depth (rooted cuttings) as plants were sequentially up canned.

Substrates were pine bark based with amendments of dolomitic lime, gypsum, controlled release fertilizers, and period supplemental fertilization as needed via fertigation. Integrated pest management methods are used to control nursery pests and diseases as needed. Irrigation was applied via hand watering when plants are small and then automated via microsprinklers below the canopy level as plants grew beyond the liner stage.

On March 26, 2010, plants were transplanted from the containers into landscape soils in the field. Trees were established on $6 \mathrm{ft}(1.8 \mathrm{~m})$ within row and $12 \mathrm{ft}(3.7 \mathrm{~m})$ between row spacings on a sandy loam soil at the Texas A\&M University Horticulture Farm in College Station, Texas. Holes were dug to the depth of the deepest planting treatment, then backfilled and tamped to the desired depth for each treatment. Sides of the holes were collapsed into the planting holes around the planted rootball to avoid glazed surfaces and the remaining soil from the hole was used to complete the backfill of the planting hole. Trees were drip irrigated throughout the first growing season in the field trial whenever soil moisture tension as measured by tensiometers in the field plots exceed $15 \mathrm{kPa}$. After the first growing season, irrigation was provided approximately weekly during the growing season as needed to avoid wilting. Weeds were controlled using manual weeding and glyphosate as needed to maintain a $2 \mathrm{ft}(0.6 \mathrm{~m})$ wide within row vegetation free area. A turf, consisting principally of bermudagrass [Cynodon dactylon (L.) C.H. Persoon], was present between the rows and was maintained at a 5.1 to 10.2 $\mathrm{cm}$ ( 2 to 4 in) height by mowing throughout the study.

Sufficient numbers of each of the four species were grown to plant factorial combinations of four planting depths $[7.6 \mathrm{~cm}$ ( 3 in) above grade, at grade, $7.6 \mathrm{~cm}$ ( 3 in) below grade, and $15.2 \mathrm{~cm}$ (6 in) below grade] and two propagation methods (rooted cuttings versus seedlings) to a landscape test site. This resulted in a 4 planting depth $\mathrm{x} 2$ propagation methods $\mathrm{x} 4$ species factorial using a randomized complete block design with four blocks containing two plants of each treatment combination per block ( 8 total replicates of each combination of treatments, 256 total plants). Measurements collected included plant height, canopy spread (diameter) within the row and perpendicular to the row, trunk diameters of the main trunk or the largest three trunks for multi-trunk species at both $15.2 \mathrm{~cm}$ (6 in) above the original rootball and at $15.2 \mathrm{~cm}$ (6 in) above the soil surface in the landscape. Plant indices were calculated as an estimation of canopy volume by multiplying height times canopy diameter within the row times canopy diameter perpendicular to the row. Trunk cross-sectional areas were calculated using the formula for the surface area of a circle and using half of the trunk diameter as an estimate of the radius. 
In February and March of 2013 the original rootballs of all surviving trees were excavated to determine the depth of the first structural root relative to the soil surface and to determine the number of lateral roots greater than 0.5 in $(1.3 \mathrm{~cm})$ emerging from the planted rootball.

The winter of 2010-2011 turned out to provide an unusual opportunity to examine the effects of the treatments in this study on cold tolerance as the plants experienced a rapid drop from growing conditions to $18^{\circ} \mathrm{F}\left(-8.8^{\circ} \mathrm{C}\right)$ within approximately 24 hours. This resulted in variable levels of shoot damage among the species and also appeared to have differential effects in some cases related to the propagation method or planting depth. Thus, we compared the fall data in 2010 versus the same measures collected the following spring of 2011 as growth resumed to determine the impacts of the cold exposure related to our treatments. The study was terminated after the third growing season in December 2012.

\section{Results and Discussion \\ Growth and dieback after exposure to $18^{\circ} \mathrm{F}\left(-8.8^{\circ} \mathrm{C}\right)$.}

The unusual event following the first growing season in the field where temperatures rapidly dropped from growing conditions to a hard freeze afforded an opportunity to assess the effects of propagation methods and planting depths on the various taxonomic related responses to this environmental challenge. When comparing the fall data from the first year with the subsequent spring's data after the cold event, the only three way interaction that was significant among taxa, propagation methods, and planting depths was for plant indices (Table 1, Fig. 1). Two way interactions were significant for trunk crosssectional trunk area relative to the original rootball for propagation method $x$ planting depths across taxa (Table 1, Fig. 2.), mortality of above ground tissues for taxa $\mathrm{x}$ planting depths across propagation methods (Table 1, Fig. 3), and for height, trunk diameters and cross-sectional areas relative to both the top of the original rootball and the soil surface (Tables 1 and 2).

\begin{tabular}{|c|c|c|c|c|c|c|c|}
\hline ANOVA & & Plant & $\begin{array}{r}\text { Change ir } \\
\text { rela }\end{array}$ & $\begin{array}{l}\text { k diameter } \\
\text { o the: }\end{array}$ & $\begin{array}{r}\text { Change in } \\
\text { re }\end{array}$ & $\begin{array}{l}\text { sectional area } \\
\text { to the: }\end{array}$ & \\
\hline Effects & Height & index & Rootball & Soil surface & Rootball & Soil surface & Die-off \\
\hline Taxa & $* * *_{\mathrm{Z}}$ & $* * *$ & $* * *$ & $* * *$ & $* * *$ & $* * *$ & $* * *$ \\
\hline $\begin{array}{c}\text { Taxa } x \\
\text { propagation }\end{array}$ & $* * *$ & $* * *$ & *** & $* * *$ & $* *$ & $* *$ & n.s. \\
\hline Taxa $\mathrm{x}$ depth & n.s. & n.s. & n.s. & n.s. & n.s. & n.s. & $* * *$ \\
\hline $\begin{array}{c}\text { Propagation } x \\
\text { depth }\end{array}$ & n.s. & n.s. & n.s. & n.s. & $*$ & n.s. & n.s. \\
\hline $\begin{array}{c}\text { Taxa } x \\
\text { propagation } x \\
\text { depth }\end{array}$ & n.s. & $*$ & n.s. & n.s. & n.s. & n.s. & n.s. \\
\hline
\end{tabular}

Table 1. Partial analysis of variance for interactions and main effects of propagation method (seed-grown versus rooted cuttings) on winter dieback associated with exposure to $18^{\circ} \mathrm{C}$ in the landscape of four species (Chilopsis linearis, Lagerstroemia indica $\mathrm{x}$ Lagerstromia fauriei, Nerium oleander, Vitex agnus-castus) planted at four planting depths $(7.6 \mathrm{~cm}$ above grade, at grade, $7.5 \mathrm{~cm}$ below grade, to $15.2 \mathrm{~cm}$ below grade).

Damage was severe enough among $N$. oleander that estimates of plant indices were not possible in the spring immediately following cold damage. Only minimal reductions in C. linearis (Fig. 1A) and V. agnus-castus (Fig. 1B) were observed in response to exposure to $18^{\circ} \mathrm{F}\left(-8.8^{\circ} \mathrm{C}\right)$ and responses of these two species in plant index estimates were statistically similar across planting depths. Alternatively, $L$. indica $\mathrm{x}$ L. fauriei (Fig. 1C) responded differently dependent upon both the propagation method and the planting depth in the field. In general, the seedling propagated Lagerstroemia incurred less damage to the canopy (less reduction in plant index) than did trees propagated from rooted cuttings (Fig. 1C). Interestingly seedling trees had slightly greater plant index reductions in response to the cold exposure than those trees planted more shallowly, whereas Lagerstroemia propagated from cuttings had the least severe plant index reductions when planted below grade (Fig. 1C). Perhaps there is something disadvantageous from a cold tolerance standpoint to adventitiously rooted cuttings versus lateral roots formed from the primary root? There are several reports in the literature in which exposure of some species propagated via adventitiously rooted shoot tips to freezing temperatures during their first winter after rooting can cause damage to the new adventitious root system (Nair and Zhang, 2010). It appears that while clonally produced Lagerstroemia were more severely affected in the canopies by cold exposure, there was some negation of cold effects on more deeply planted cutting propagated trees (Fig. 1C), but other adverse effects of suboptimal planting 
depths may offset this benefit and seedling grown Lagerstroemia survived the cold event better than the rooted cutting derived trees at all planting depths (Fig. 1C).
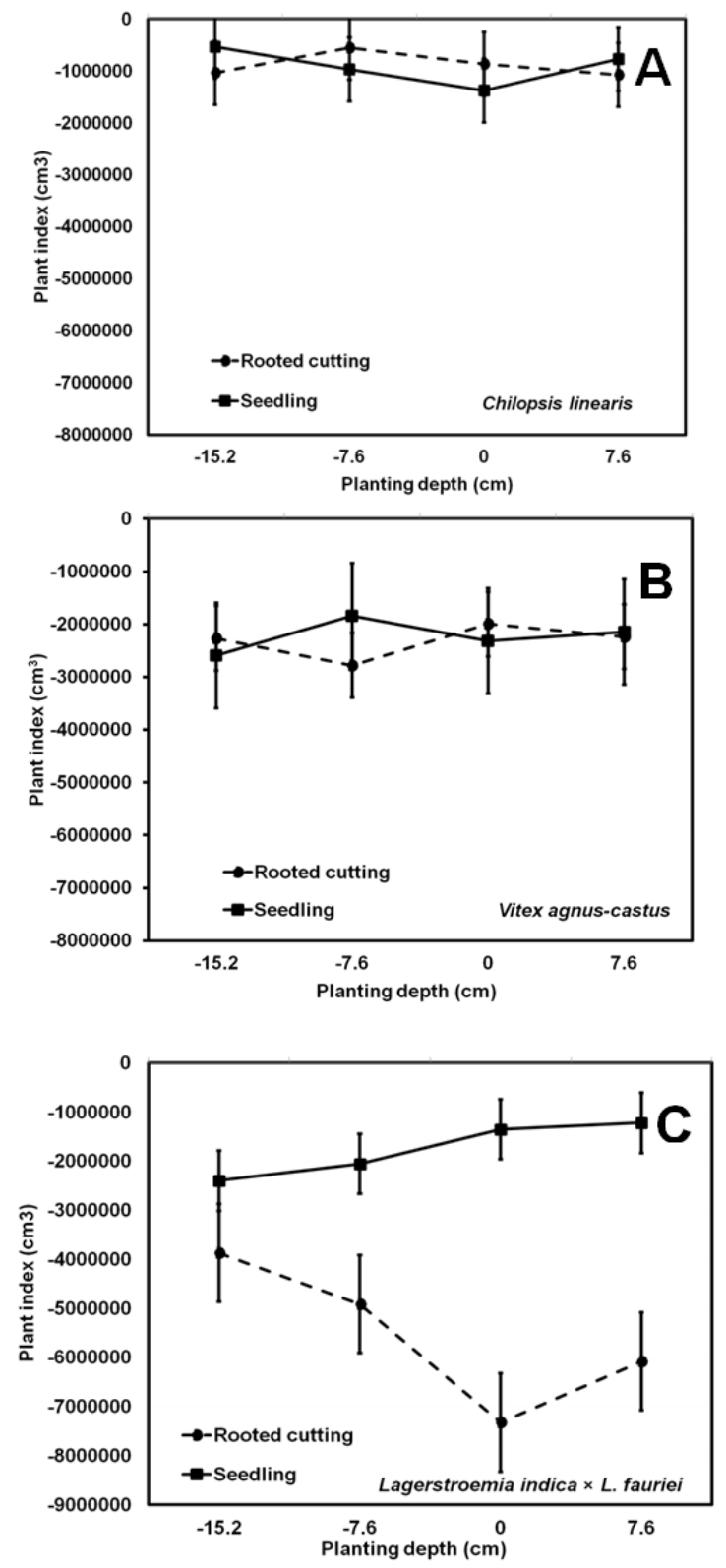

Figure 1. Three way interactions on reductions in plant indices among taxa [C. linearis (A), V. agnus-castus (B), L. indica $\mathrm{x}$ L. fauriei (C)], propagation method, and planting depth in the landscape. Nearly $100 \%$ of the Nerium oleander cuttings and seedlings died back to the soil line after exposure to $18^{\circ} \mathrm{F}\left(-8.8^{\circ} \mathrm{C}\right)$ and are not represented graphically. Symbols represent the means ( \pm standard errors) of eight observations.

An interactions among taxa and planting depths across propagation methods occurred for canopy tissue survival following exposure to $18^{\circ} \mathrm{F}\left(-8.8^{\circ} \mathrm{C}\right)$ temperatures (Fig. 2). Exposure to low temperature had only minimal effects on the canopy survival of Lagerstroemia, Chilopsis, and Vitex, whereas Nerium canopy tissue survival was substantially reduced for plants planted above grade, probably due to the increased tissue exposure above the insulating effects of the soil (Fig. 2).

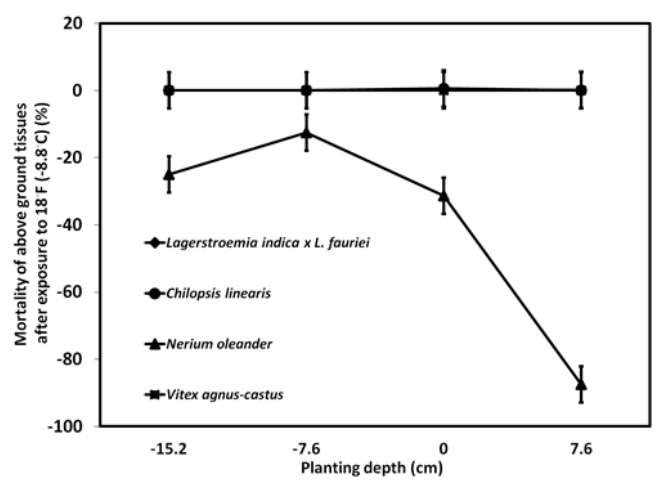

Figure 2. Two way interactions among taxa and planting depths across propagation method on winter survival after exposure to $18^{\circ} \mathrm{F}\left(-8.8^{\circ} \mathrm{C}\right)$, symbols represent means $( \pm$ standard errors) of 16 observations. Overlapping of symbols occur at all levels for $L$. indica x L. fauriei, C. linearis, and $V$. agnus-castus where survival of above ground tissues was essentially $100 \%$.

A significant interaction among planting depths and propagation methods across taxa was present for trunk crosssectional area relative to the depth of the original planted rootball (Table 1, Fig. 3). Trunk cross-sectional area relative to the planted rootball was greater on surviving seedlings across taxa with a peak for those planted at grade, least for those planted above grade, and intermediate for those planted below grade (Fig. 3). In contrast, plants generated from rooted cuttings had greater trunk diameter on surviving plants transplanted below grade while those transplanted above and at grade were smaller (Fig. 3). Thus, the least negative impact on cross-sectional trunk area from exposure to $18^{\circ} \mathrm{F}\left(-8.8^{\circ} \mathrm{C}\right)$ was with seedlings transplanted at grade and the most negative impact was with rooted cuttings planted at or above grade (Fig. 3).

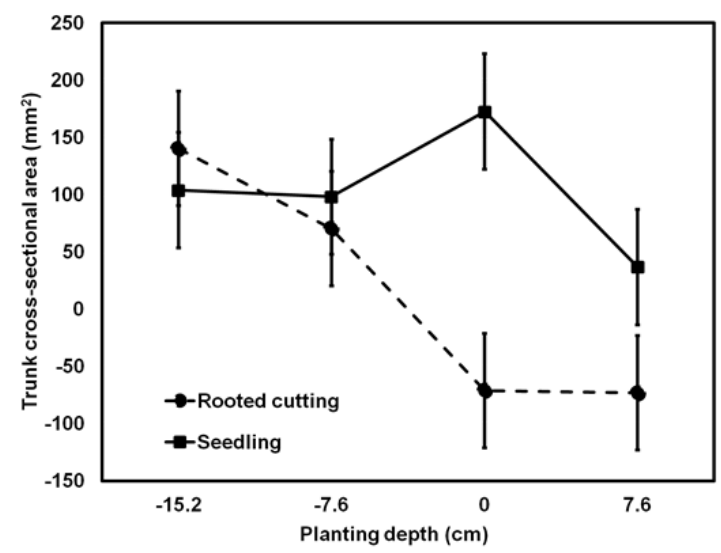

Figure 3. Two way interactions among propagation methods and planting depths across taxa in response to winter exposure to $18^{\circ} \mathrm{F}\left(-8.8^{\circ} \mathrm{C}\right)$ on changes in trunk cross sectional area; 
symbols indicate the means ( \pm standard errors) of observations of 32 individuals.

Two way interactions among taxa and propagation methods were present following exposure to $18^{\circ} \mathrm{F}\left(-8.8^{\circ} \mathrm{C}\right)$ in which Chilopsis linearis and Nerium oleander were not different between propagation methods for height, trunk diameter and trunk cross-sectional area either in relation to the planted rootball or soil surface (Table 2), while rooted cutting generated trees of Lagerstroemia were adversely affected by cold exposure for all of these same characteristics compared to seedling derived Lagerstroemia (Table 2). Vitex agnus-castus was equally adversely affected by exposure to $18^{\circ} \mathrm{F}\left(-8.8^{\circ} \mathrm{C}\right)$ for either propagation measure, except for less trunk crosssectional area relative to the soil surface for surviving rooted cutting derived trees (Table 2).

\begin{tabular}{|c|c|c|c|c|c|c|}
\hline \multirow[b]{2}{*}{ Taxa } & \multirow[b]{2}{*}{$\begin{array}{l}\text { Propagation } \\
\text { method }\end{array}$} & \multirow[b]{2}{*}{$\begin{array}{c}\text { Height } \\
\text { (cm) }\end{array}$} & \multicolumn{2}{|c|}{$\begin{array}{c}\text { Trunk diameter relative } \\
\text { to: }\end{array}$} & \multicolumn{2}{|c|}{$\begin{array}{l}\text { Cross-sectional area } \\
\text { relative to: }\end{array}$} \\
\hline & & & $\begin{array}{l}\text { Rootball } \\
(\mathbf{m m})\end{array}$ & Soil (mm) & $\begin{array}{c}\text { Rootball } \\
(\mathbf{m m 3})\end{array}$ & $\begin{array}{c}\text { Soil } \\
(\mathbf{m m 3})\end{array}$ \\
\hline \multirow{2}{*}{$\begin{array}{c}\text { Lagerstroemia indica } \times L \text {. } \\
\text { fauriei }\end{array}$} & Rooted cutting & $-122.6 b^{z}$ & $-10.7 b$ & $-14.3 b$ & $-199 \mathrm{~b}$ & $-266 b$ \\
\hline & Seedling & $-38.2 \mathrm{a}$ & $1.0 \mathrm{a}$ & $0.9 \mathrm{a}$ & $51 \mathrm{a}$ & $58 \mathrm{a}$ \\
\hline \multirow[t]{2}{*}{ Chilopsis linearis } & Rooted cutting & $-32.8 \mathrm{a}$ & $1.5 \mathrm{a}$ & $0.7 \mathrm{a}$ & $43 \mathrm{a}$ & $26 \mathrm{a}$ \\
\hline & Seedling & $-50.3 a$ & $2.0 \mathrm{a}$ & $1.9 \mathrm{a}$ & $62 \mathrm{a}$ & $57 \mathrm{a}$ \\
\hline \multirow[t]{2}{*}{ Vitex agnus-castus } & Rooted cutting & $-45.9 \mathrm{a}$ & $4.3 \mathrm{a}$ & $2.7 \mathrm{a}$ & $206 \mathrm{a}$ & $112 \mathrm{~b}$ \\
\hline & Seedling & $-34.4 \mathrm{a}$ & $3.6 \mathrm{a}$ & $4.5 \mathrm{a}$ & $196 \mathrm{a}$ & $230 \mathrm{a}$ \\
\hline \multirow[t]{2}{*}{ Nerium oleander } & Rooted cutting & $-142.0 \mathrm{a}$ & $-21.9 a$ & $-21.6 a$ & $-395 a$ & $-387 a$ \\
\hline & Seedling & $-158.8 \mathrm{a}$ & $-21.2 \mathrm{a}$ & $-20.5 \mathrm{a}$ & $-387 \mathrm{a}$ & $-345 \mathrm{a}$ \\
\hline
\end{tabular}

${ }^{\mathrm{z}}$ Means within a column and taxa followed by the same letter are significantly different $(P \leq 0.05)$ using least squares means procedures; values represent means of 32 observations.

Table 2. Two way interactions among taxa and propagation method (seed-grown versus rooted cuttings) on winter dieback measures associated with exposure to $-8.8 \mathrm{C}\left(18^{\circ} \mathrm{F}\right)$ in the landscape of four species (Chilopsis linearis, Lagerstroemia indica $\mathrm{x}$ Lagerstromia fauriei, Nerium oleander, Vitex_agnus-castus $)$ planted at four planting depths $(7.6 \mathrm{~cm}$ above grade, at grade, $7.5 \mathrm{~cm}$ below grade, to $15.2 \mathrm{~cm}$ below grade); values represent means of 32 observations.

Growth and survival after three years in the landscape.

After three growing seasons in the landscape, no three way interactions were significant $(P \leq 0.05)$ for measured characteristics (Table 3). Two way interactions were present for plant indices for propagation method $\mathrm{x}$ planting depth across taxa (Table 3, Fig. 4), taxa x planting depth for trunk cross-sectional area relative to the rootball and survival (Table 3, Fig. 5), and taxa $x$ plant propagation across planting depths for height (Table 3 and 4). The main effects of planting depth were also significant for trunk diameter relative to the rootball across taxa and propagation methods (Table 3, Fig. 6).

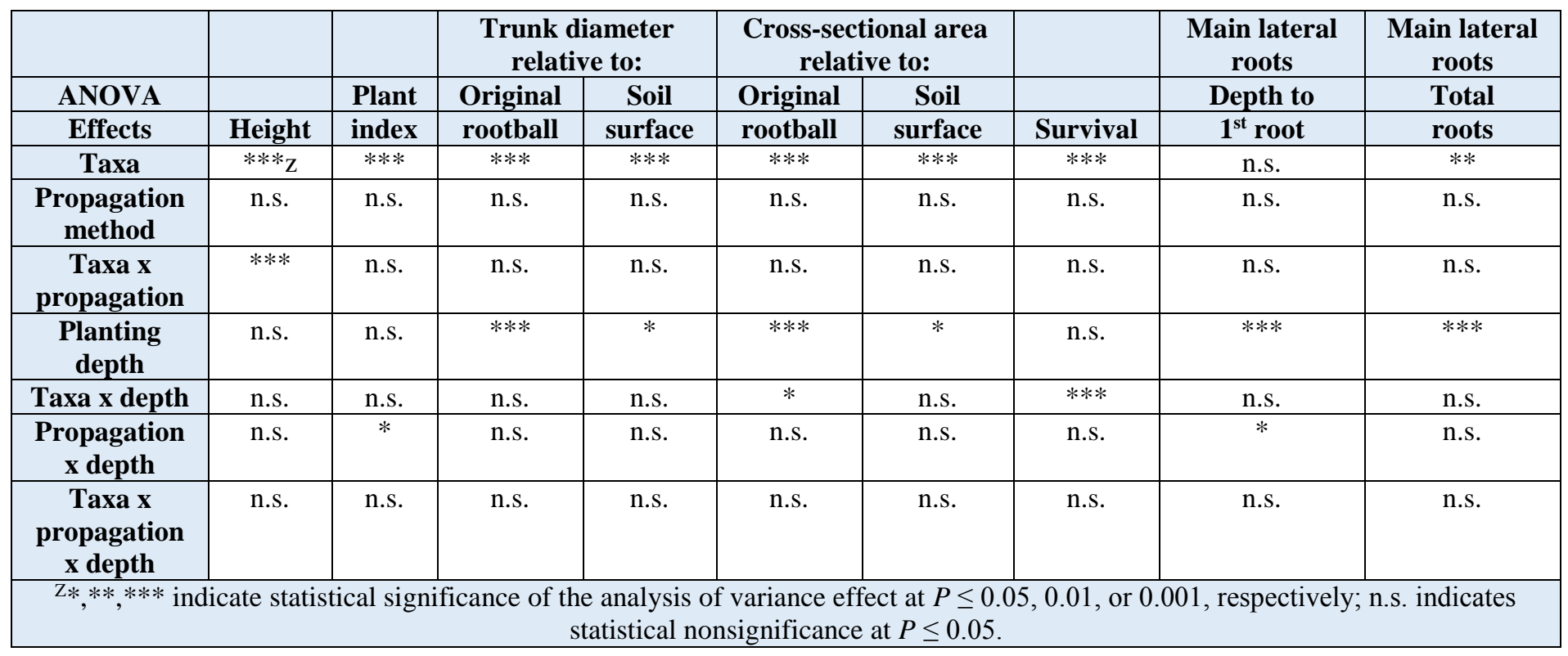

Table 3. Partial analysis of variance for interactions and main effects of propagation method (seed-grown versus rooted cuttings) on growth for three years in the landscape of four species (Chilopsis linearis, Lagerstroemia indica $\mathrm{x}$ Lagerstromia fauriei, Nerium 
oleander, Vitex agnus-castus) planted at four planting depths ( $7.6 \mathrm{~cm}$ above grade, at grade, $7.5 \mathrm{~cm}$ below grade, to $15 \mathrm{~cm}$ below grade).

After three years in the landscape, there was a two way interaction among planting depths and propagation methods across all taxa (Table 3, Fig. 4). When planted at grade, seedlings tended to produce larger plant indices than cutting propagated materials (Fig. 4). When planted below grade plant indices were reduced for plants produced using both propagation methods, but tended to be more so for seedling produced plants (Fig. 4). Plant indices averaged across taxa were also reduced when trees were planted above grade, more so for cutting propagated plants (Fig. 4). Interestingly, planting below grade reduced survival of all taxa, but $N$. oleander (Fig. 5). This was particularly the case for $C$. linearis which is an arid land species known to be intolerant of poorly drained soils (Arnold, 2008). Lagerstroemia and Vitex are known to tolerate heavier soils and were previously reported to have less adverse responses to suboptimal planting (Arnold et al., 2007). In prior studies $N$. oleander survival and growth were reduced by below grade planting (Arnold et al., 2007), but the overall lower survival of $N$. oleander planted at or above grade in the present study may be a residual effect of the cold exposure in the winter of 2010-2011 which damaged $N$. oleander much more so than other species. For surviving trees, planting below grade reduced the cross-sectional area of C. linearis regardless of propagation method (Fig. 5), which was consistent with survival results. However, it is interesting to note that above grade planting of $C$. linearis increased survival, but reduced trunk cross-sectional area (Fig. 5). Planting depth had only minimal impact on final crosssectional trunk diameter of $N$. oleander, but had substantial effects on survival (Fig. 5). For V. agnus-castus or L. indica $\mathrm{x}$ L. fauriei survival was slightly less at greater planting depths, but the trunk cross sectional area of surviving trees after three years was similar or slightly increased in comparison to trees at grade (Fig. 5). Planting above grade had no effect or slightly increased survival of $V$. agnus-castus or L. indica x $L$. fauriei, but resulted in considerable reductions in trunk crosssectional area of the surviving trees (Fig. 5).

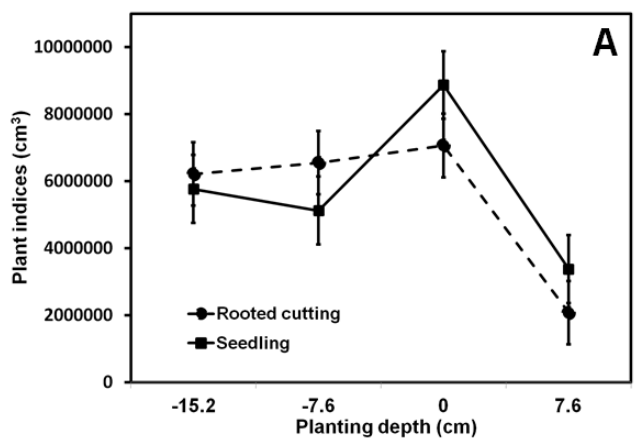

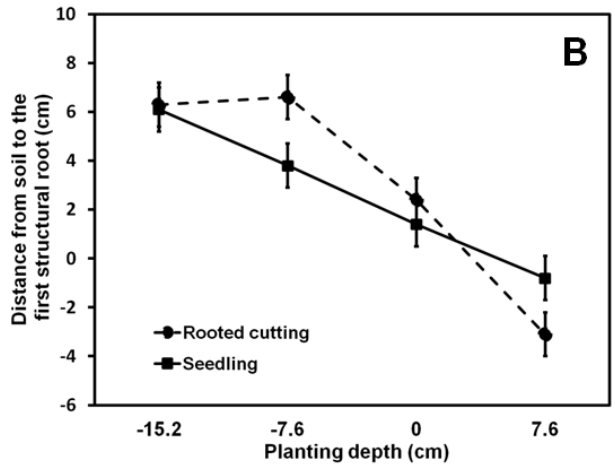

Figure 4. Two way interactions among propagation methods and planting depths across four taxa of landscape plants on plant indices and distance from the soil surface to the first structural root after three growing seasons in the landscape. Symbols represent means $( \pm$ standard errors) of 64 observations.
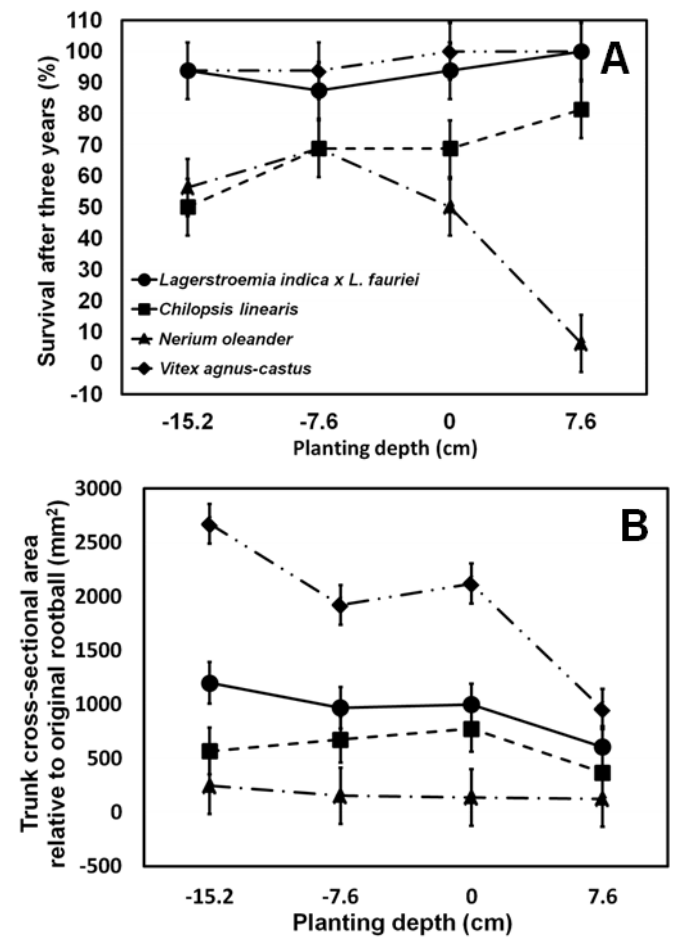

Figure 5. Two way interactions for overall survival (A) and trunk cross sectional area relative to the original rootball (B) after three years in the landscape among species and planting depths across propagation methods. Symbols represent means ( \pm standard errors) of 16 observations.

Averaged across propagation methods and taxa, the overall responses of trunk diameter to planting depths was to grow largest when planted at grade and result in a reduction in growth when planting either above or below grade (Fig. 6). Residual effects of propagation method differed among species in height growth after three years in the landscape 
(Table 4). Seedling and cutting propagated V. agnus-castus were nearly identical in mean height. While final height of cutting propagated L. indica x L. fauriei and N. oleander were taller than seedling propagated plants, with $C$. linearis responding inversely with seedling propagated trees growing taller than clonally propagated trees (Table 4).

\begin{tabular}{|c|c|c|}
\hline Taxa & Propagation method & Height (cm) \\
\hline \multirow[b]{2}{*}{ Lagerstroemia indica $x$ L. fauriei } & Rooted cutting & $286 \mathrm{a}^{\mathrm{z}}$ \\
\hline & Seedling & $249 \mathrm{~b}$ \\
\hline \multirow[b]{2}{*}{ Chilopsis linearis } & Rooted cutting & $184 \mathrm{~b}$ \\
\hline & Seedling & $224 \mathrm{a}$ \\
\hline \multirow[b]{2}{*}{ Vitex agnus-castus } & Rooted cutting & $250 \mathrm{a}$ \\
\hline & Seedling & $247 \mathrm{a}$ \\
\hline \multirow[b]{2}{*}{ Nerium oleander } & Rooted cutting & $153 \mathrm{a}$ \\
\hline & Seedling & $110 \mathrm{~b}$ \\
\hline
\end{tabular}

Table 4. Two way interactions among taxa and propagation method (seed-grown versus rooted cuttings) across planting depths on height growth of after three years in the landscape of four species (Chilopsis linearis, Lagerstroemia indica $\mathrm{x}$ Lagerstromia fauriei, Nerium oleander, Vitex agnus-castus) planted; values represent means of 32 observations.
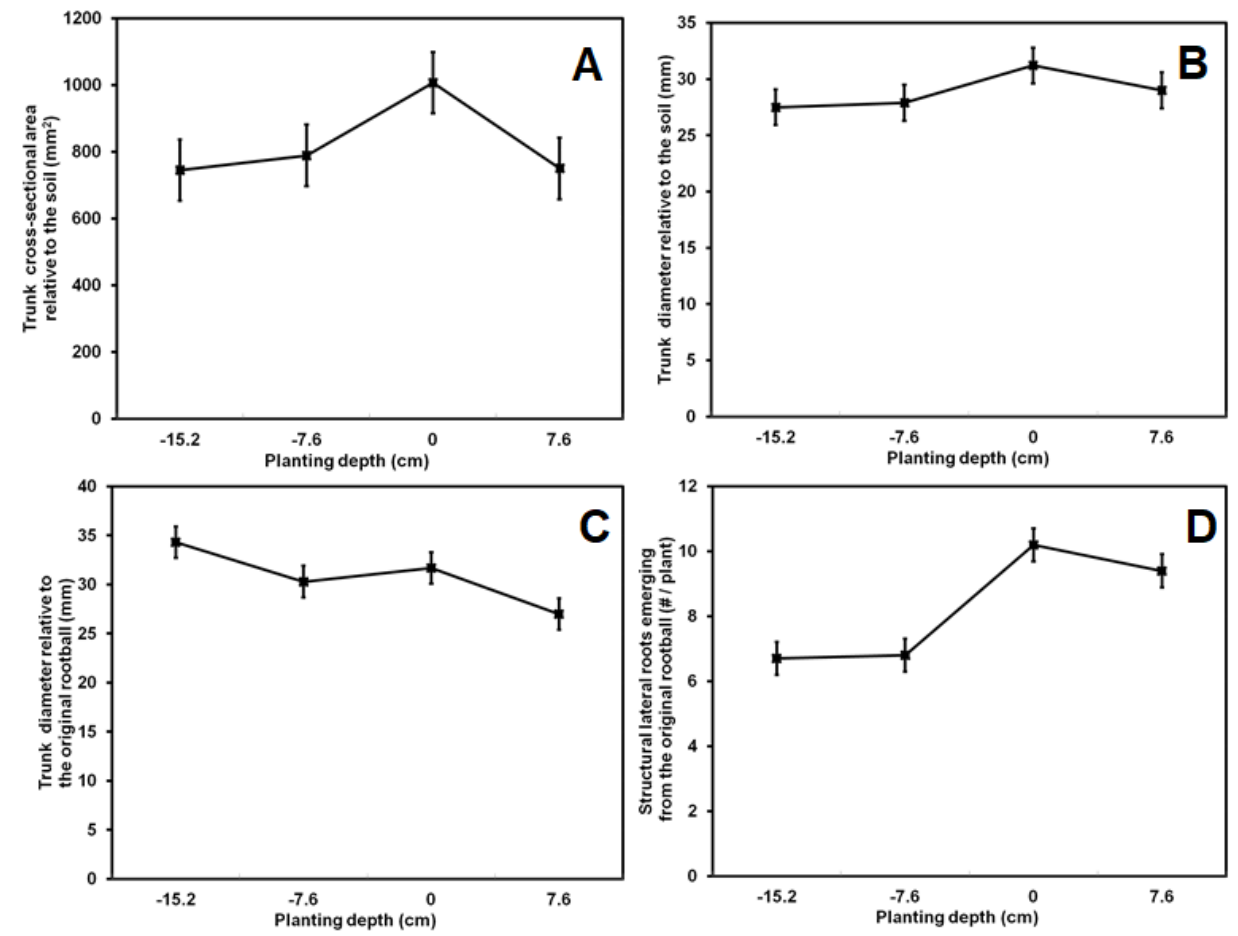

Figure 6. Main effect of planting depth across taxa and propagation method on trunk cross-sectional area (A) and trunk diameter relative to soil (A), trunk diameter relative to the original rootball $(\mathrm{C})$, and the number of main lateral roots regenerated from rootballs (D) after three years in the landscape. Symbols are means ( \pm standard errors) of 64 observations.

\section{Conclusions}

This study provides insights into the complexities associated with interpreting the results of below grade planting studies. Reports from around the country have differed among researchers, varying from little or no effect of below grade planting to extremely adverse effects. Results of this study have confirmed that apparently species which are more naturally tolerant of poorly drained soils, such as $V$. agnuscastus are little impacted by planting depth or method of propagation. While other trees less well adapted to poorly drained conditions, such as $C$. linearis can be very adversely impacted by the same suboptimal planting depths even in the same study site. Propagation method was a previously uninvestigated factor relative to planting depth. Some residual effects of seedling versus cutting propagated trees were present three years after transplant to the landscape. This factor had some interesting interactions with tolerance to cold temperatures and planting depth. Propagation method and exposure to various levels of winter cold may also complicate 
prediction of responses of taxa that grow across a range of temperature to planting at suboptimal planting depths.

\section{Acknowledgements}

${ }^{1}$ Professor of Landscape Horticulture and Director of The Gardens at Texas A\&M University, former Lecturer, and former Graduate Teaching/Research Assistant, respectively, Texas A\&M University, Department of Horticultural Sciences, 2133 TAMU, College Station, TX 77843-2133, 979845-1499, ma-arnold@tamu.edu, The authors would like to gratefully acknowledge the monetary support from the Tree Research and Education Endowment Fund (TREE Fund) and NIFA through Hatch funds to Texas A\&M AgriLife Research.

${ }^{2}$ Invironmental Horticulture Program Coordinator and Professor, University of Wisconsin - Platteville, School of Agriculture, 312 Pioneer Tower, Platteville, WI 53518, cartmilld@uwplatt.edu

\section{Literature Cited}

1. Arnold MA (2008). Landscape Plants for Texas and Environs, Third Edition. Stipes Publ. L.L.C., Champaign, IL. 1334.
2. Arnold MA, GV McDonald (2009). Groundcovers, organic and inorganic mulches, and masonry surfaces differentially affect establishment and root zone characteristics of urban trees. Arboriculture and Urban Forestry 35:232-240.

3. Arnold MA, GV McDonald, DL Bryan (2005). Planting depth and mulch thickness affect establishment of green ash and bougainvillea goldenraintree. J. Arboriculture 31:163-170.

4. Arnold MA, GV McDonald, DL Bryan, GC Denny, WT Watson et al. (2007). Below grade planting adversely affects survival and growth of tree species from five different families. Arboriculture \& Urban Forestry 33:6469.

5. Bryan DL, MA Arnold, A Volder, WT Watson, L Lombardini et al. (2009). Overview of selected studies on the influence of planting depth on landscape establishment of container-grown trees. pp. 126-130. In: The Landscape Below Ground III: Proc. of an International Workshop on Tree Root Development in Urban Soils. Lisle, IL, Oct. 7-9, 2008.

6. Nair A, D Zhang (2010). Propagation of Stewartia: past research endeavors and current status. HortTechnology 20:277-282.

Citation: Arnold MA, King AR, Carver ST, Cartmill DL (2021) Propagation Method Impacts Survival and Growth of Below Grade Planted Trees. Adv Agri Horti and Ento: AAHE-147. 